Jurnal Mandala Pharmacon Indonesia, Vol 3.No.2 Desember 2017

Avaiable online at www.jurnal-pharmaconmw.com/jmpi

$p$-ISSN :2442-6032

$e$-ISSN :2598-9979

\title{
Uji Daya Hambat Sediaan Sabun Transparan Ekstrak Jarak Pagar (Jatropha curcas) Terhadap Pertumbuhan Bakteri Uji Propionibacterium acnes
}

\author{
Risky Juliansyah*1, Rismawati Paotonan² \\ 1STIKES Mandala Waluya Kendari \\ ${ }^{2}$ Universitas Islam Makassar
}

\begin{abstract}
ABSTRAK
Jerawat merupakan penyakit peradangan yang terjadi akibat penyumbatan pada pilosebasea yang ditandai dengan adanya komedo, papul, pastul, dan bopeng (scar) pada daerah wajah, leher, lengan atas, dada, dan punggung. Peradangan dipicu oleh Propionibacterium acne, Staphylococcus epidermidis, dan Staphylococcus aureus. Kandungan fitokimia dalam daun Jarak pagar yaitu tanin, steroid dan triterpenoid, flavanoid, saponin, antraquinon, dan alkaloid. Dalam formulasi sabun transparan penambahan bahan aktif tanaman dapat membantu peningkatan aktivitas antibakteri.

Dari hasil penelitian uji daya hambat sabun transparan ekstrak jarak pagar (Jatropha curcas) terhadap pertumbuhan Bakteri Propionibacterium acnes menghasilkan zona hambatan pertumbuhan pada bakteri dengan konsentrasi hambatan minimum yaitu $5 \%$. Untuk
\end{abstract}

kontrol positif sendiri digunakan ekstrak jarak pagar memberikan diameter hambat sebesar $11,02 \mathrm{~mm}$ serta pada kontrol negatif digunakan sabun transparan tanpa penambahan ekstrak jarak pagar memberikan diameter hambatan sebesar $5,32 \mathrm{~mm}$. Sehingga konsentrasi minimum pada penghambatan pertumbuhan bakteri uji pada sediaan sabun transparan pada konsentrasi 5\% dengan diameter hambatan 9,07 mm.

Kata kunci :Sabun transparan, Aktivitas Anti bakteri, Uji daya hambat

\section{Penulis korespondensi}

Risky Juliansyah

STIKES Mandala Waluya kendari

riskyyuliansyah88@gmail.com

\section{PENDAHULUAN}

Tanaman jarak pagar (Jatropha curcas) termasuk famili Euphorbiaceae, merupakan tanaman tahunan yang toleran kekeringan. Tanaman ini berasal dari Amerika Latin dan menyebar di daerah tropika baik pada iklim kering dan setengah-kering. Bijinya beracun dan mengandung sekitar 35\% minyak. Jarak pagar merupakan tanaman multifungsi, karena dapat menghasilkan bahan bakar alternatif, bahan pembuat sabun, dan kulit buah/kapsul dapat dijadikan kompos. Di samping itu, jarak pagar juga merupakan tanaman obat (bijinya untuk obat sembelit, getahnya untuk obat luka, daunnya sebagai anti malaria) (Henning, 1998).

Menurut Oyi (2007), jarak pagar (Jatropha curcas) memiliki aktivitas antimikroba 
yang baik untuk bakteri gram-negatif maupun bakteri gram positif. Jarak pagar (Jatropha curcas) mengandung beberapa kandungan kimia, yaitu tanins, flavonoid, dan saponins yang terdapat didalam getah tanaman jarak pagar (Jatropha curcas). Zat tanin dapat menyebabkan kompleksasi terhadap enzim atau substrat yang terdapat pada dinding sel bakteri sehingga menyebabkan koagulasi protein pada dinding sel bakteri dengan konsentrasi tanin yang tinggi. Pada suatu penelitian, zat tanin efektif menghambat pertumbuhan bakteri di saluran pencernaan, seperti Acteroides fragilis, Clostridium perfringens, Escherichia coli and Enterobacter cloacae dan bakteri lainnya (Akiyama, 2001).

\section{Metodologi}

\section{Waktu dan Tempat penelitian}

enelitian ini telah dilakukan pada bulan Oktober - November 2009 - 2010 bertempat di laboratorium Fitokimia Farmakognosi program studi Farmasi Universitas Islam makassar.

\section{Bahan}

Bahan yang digunakan dalam penelitian ini adalah aquadest, ekstrak Jarak pagar ,Gliserin, Minyak kelapa, asam sterarat,
$\mathrm{NaOH}$, Gula, asam sitrat, SIS, Etanol 96\%, dan Media agar NA.

\begin{abstract}
Alat
Alat yang digunakan dalam penelitian yaitu batang pengaduk, Mortir stamper, cawan petri, Botol vial, mistar, jangka pengukur, Toples, dan Rotavapor.
\end{abstract}

\section{Prosedur}

\section{Penyiapan Sampel}

Daun kering Jarak pagar dikeringkan dengan cara diangin-anginkan kemudian dilakukan sortasi kering. Kemudian sampel daun kering dimasukkan dalam toples maserasi untuk diekstraksi dengan pelarut etanol $96 \%$ selama 7 hari dengan perbandingan 1; 7,5 yaitu dengan $500 \mathrm{mg}$ sampel dan $3750 \mathrm{ml}$ pelarut Ekstrak kemudian dipekatkan di rotapavor hingga diperoleh ekstrak kental daun, yang akan digunakan sebagai bahan pembuatan sabun transparan.

\section{Formulasi Sediaan sabun transparan}

Ditimbang Semua bahan sesuai dengan perhitungan bahan kemudian Asam stearat dilelehkan pada suhu $60^{\circ}-70^{\circ} \mathrm{C}$ dengan bantuan spatula. Minyak Kelapa dicampurkan pada asam stearat (dengan bantuan mixer) pada suhu konsisten 
hingga homogen. $\mathrm{NaOH} \quad 40 \%$ dituangkan pada campuran asam stearat dan ekstrak jarak pada suhu $70^{\circ}$ $80^{\circ} \mathrm{C}$ (Proses Penyabunan). Diaduk terus menerus hingga homogen. Pada suhu $70^{\circ}-80^{\circ} \quad \mathrm{C}$ dilakukan pencampuran etanol, gliserin, larutan gula (gula dan air), SLS, asam sitrat diaduk hingga homogen. Suhu diturunkan hingga $40^{\circ}$, dan ditambahkan pewangi dan ekstrak daun jarak pagar. Massa cair sabun ini merupakan sabun yang siap cetak. Pada suhu $30^{\circ}$ sabun dapat mengeras dalam semalam dan dapat dipotong menjadi beberapa bagian.

\begin{tabular}{lc}
\hline Nama Bahan & Jumlah $(\mathrm{g})$ \\
\hline Asam stearat & 7 \\
\hline Minyak Kelapa & 100 \\
\hline Ekstrak jarak & 100 \\
\hline NaoH & 18 \\
\hline Etanol & 15 \\
\hline Gliserin & 13 \\
\hline & \\
Gula & 7,5 \\
\hline Asam sitrat & 5 \\
\hline Na lauryl sulfat & 5 \\
\hline Aquadest & q.s \\
\hline
\end{tabular}

\section{Pengujian daya hambat}

Peremajaan mikroba uji

Peremajaan kultur murni mikroba uji BakteriPropionibacterium acnes diambil dari biakan sebanyak satu ose kemudian diinokulasi pada medium NA miring. Bakteri uji diinkubasi selama 24 jam pada suhu $37^{\circ} \mathrm{C}$, Setelah itu dapat digunakan sebagai mikroba uji.

\section{Pembuatan suspensi mikroba uji}

Mikroba uji hasil peremajaan, kemudian disuspensikan dengan larutan $\mathrm{NaCl}$ fisiologis $\quad 0,9 \%$ yang kemudian dicampurkan dengan media NA steril dan dimasukkan kedalam cawan petri, dimana sebelumnya telah dimasukkan base layer berupa agar NA yang telah memadat, Kemudian diinkubasi pada suhu $37{ }^{\circ} \mathrm{C}$ selama 24 jam.

\section{Pengukuran zona hambatan}

Cawan petri yang telah diinkubasi selama 2x 24 jam kemudian diamati dan diukur diameter hambatan pada cawan petri menggunakan jangka pengukur.

\section{Hasil dan Pembahasan}

Telah dilakukan penelitian mengenai uji daya hambat sabun transparan ekstrak Jarak pagar terhadap pertumbuhan bakteri Propionibacterium acnes dengan menggunakan metode difusi agar kertas cakram (paper dish). hasil pengamatan mengenai berupa penghambatan pertumbuhan bakteri dalam media uji. 
Zat aktif yang digunakan berupa ekstrak jarak pagar yang mengandung senyawa flavanoid, tanin dan saponin yang memiliki aktivitas antibakteri terhadap beberapa jenis bakteri.

Sampel jarak pagar (Jatropha curcas) diolah dengan metode maserasi. Pembuatan ekstrak (maserasi) dilakukan karena disamping pengerjaan dan peralatan yang digunakan sederhana serta mudah diusahakan, dan sampel juga merupakan jenis sampel lunak. Pelarut yang digunakan untukmaserasi yaitu etanol 96\% karena merupakan pelarut semipolar, dengan demikian pelarut tersebut dapat menyari komponen kimia yang bersifat polar maupun nonpolar selain itu struktur dari sampel yang lunak dan juga untuk menjaga agar senyawa kimia dalam sampel tidak rusak. Penggunaan etanol 96\%karena memiliki kandungan air yang sedikit sehingga menghindari rusaknya ekstrak dengan tumbuhnya jamur serta tidak toksik.

Setelah diperoleh ekstrak kental jarak pagar kemudian ekstrak ini dibuat menjadi sediaan sabun transparan. Karakteristik sabun yang dihasilkan biasanya dipengaruhi oleh distribusi dari asam-asam lemak yang digunakan
(George , 2010). Asam - asam lemak yang digunakan pada penelitian ini berasal dari minyak kelapa.

Dalam formulasi pembuatan sabun transparan jarak pagar sebagai zat aktif, bahan saponifikasi berasal dari minyak kelapa, asam stearat, dan $\mathrm{NaOH}$, Gliseril sebagai humektan, etanol sebagai pelarut, gula sebagai penstabil dan sebagai agen transparansi,asam sitrat sebagai pendapar, SLS sebagai bahan surfaktan serta ditambahkan bahan pewangi.

Metode pembuatan sabun sendiri didasarkan pada proses saponifikasi dari pencampuran minyak kelapa dan minyak jarak dengan larutan $\mathrm{NaOH}$ agar diperoleh sediaan sabun padat, setelah itu ditambahkan asam stearat yang telah dilelehkan pada suhu $70^{\circ} \mathrm{C}$ kemudian didinginkan hingga mencapai suhu 60 $50^{\circ} \mathrm{C}$ kemudian ditambahkan kembali larutan $\mathrm{NaOH}$ untuk mengurangi busa dengan perubahan pHnya kemudian ditambahkan gliserol dan etanol setelah dipanaskan pada suhu kontans $70^{\circ} \mathrm{C}$ setelah ditambahkan asam sitrat dan SLS dan didinginkan kemudian ditambahkan bahan pewangi. 
diameter zona hambat ekstrak Daun Kucai terhadap pertumbuhan

Streptococcus mutans, masa inkubasi 24 jam pada suhu $37^{\circ} \mathrm{C}$ dapat dilihat pada table 2.

Tabel.2 Hasil Uji daya hambat

\begin{tabular}{|c|c|c|c|c|c|c|}
\hline \multirow[t]{2}{*}{ Replikasi } & \multicolumn{5}{|c|}{$\begin{array}{l}\text { Diameter hambatan dengan konsentrasi Sabun Transparan } \\
\text { ekstrak daun jarak pagar }\end{array}$} & \multirow[t]{2}{*}{ jumlah } \\
\hline & $5 \%$ & $10 \%$ & $15 \%$ & Kontrol positif & Kontrol negatif & \\
\hline $\mathrm{I}$ & 9,07 & 9,23 & 10,24 & 11,02 & 5,32 & \\
\hline II & 9,14 & 12,03 & 13,07 & 11,29 & 8,19 & \\
\hline III & 10,24 & 11,15 & 11,22 & 14,33 & 9,24 & \\
\hline Jumlah & 20,03 & 32,41 & 34,53 & 36,64 & 22,75 & 146,36 \\
\hline Rata-rata & 6,67 & 10,8 & 11,51 & 12,21 & 7,58 & \\
\hline
\end{tabular}

Pada penelitian ini digunakan metode pengukuran dengan menggunkan Metode difusi kertas cakram (paper dish) yang merupakan metode penentuan zona hambatan suatu bahan antimikroba. Metode ini dipilih karena memiliki kelebihan yaitu sederhana untuk dilakukan dan dapat digunakan untuk melihat sensitivitas berbagai jenis mikroba terhadap antimikroba pada konsentrasi tertentu. Kekurangan dari metode difusi agar adalah senyawa antimikroba yang akan di uji harus bersifat hidrofilik agar dapat berdifusi dengan baik ke dalam agar.

Metode pengujian dengan menggunakan difusi agar kertas cakram (paper dish) dimana kertas cakram direndam dalam sediaan sabun transparan yang dilelehkan kemudian dibuat diletakkan pada seed layer dari medium agar ini untuk menentukan komponen antimikroba pada sediaan sabun transparan yang akan berdifusi ke dalam agar yang telah terkandung bakteri uji .

Dari hasil penelitian uji daya hambat ekstrak jarak pagar (Jatropha curcas) terhadap pertumbuhan Bakteri Propionibacterium acnes menghasilkan zona hambatan pertumbuhan pada bakteri dengan konsentrasi hambatan yaitu $5 \%, 10 \%$ dan $15 \%$ berturut turut memiliki diameter hambatan sebesar 9,07 
$\mathrm{mm}, 9,23 \mathrm{~mm}$ dan 10,24 mm. Untuk kontrol positif sendiri digunakan ekstrak daun jarak pagar memberikan diameter hambat sebesar 11,02 $\mathrm{mm}$ serta pada kontrol negatif digunakan sabun transparan tanpa penambahan ekstrak daun jarak pagar memberikan diameter hambatan sebesar 5,32 $\mathrm{mm}$.

Diameter rata - rata zona hambatan pada konsentrasi 15\% b/v yaitu sebesar 11,51 mm lebih besar dibandingkan pada konsentrasi $5 \%$ dan $10 \%$, hal ini dapat disimpulkan bahwa semakin tinggi konsentrasi ekstrak maka semakin banyak zat aktif yang berpotensi sebagai antibakteri dalam sediaan yang ditunjukkan dengan diameter zona hambatan yang semakin luas.

Pada kontrol negatif menunjukkan diameter hambatan rata-rata sebesar 7,58 $\mathrm{mm}$, hal ini disebabkan karena formulasi sabun transparan yang memiliki kemampuan sebagai antibakteri. Asam sitrat adalah bahan tambahan dalam formulasi sabun selain sebagai bahan pengkhelat pada sabun juga dapat berfungsi sebagai bahan pengawet, pencegah berubahnya warna serta mencegah terjadi oksidasi, memperbesar daya hambat dari sediaan sabun transparan ekstrak jarak pagar.

\section{Kesimpulan}

Dari hasil penelitian dapat disimpulkan bahwa:

a. Sediaan sabun transparan ekstrak jarak pagar dengan variasi konsentrasi $5 \%$, $10 \%$ dan $15 \%$ mempunyai aktivitas daya hambat pertumbuhan bakteri uji Propionibacterium acnes

b. Konsentrasi Daya hambat minimum (KHM) penghambatan sabun transparan ekstrak Jarak pagar yang diperoleh pada penelitian ini yaitu pada konsentrasi $5 \%$ dengan diameter hambatan rata- rata sebesar $6,67 \mathrm{~mm}$

\section{Saran}

1. perlu dilakukan penelitian selanjutnya mengenai pengujian pada formulasi sediaan sabun transparan dari ekstrak jarak pagar seperti uji pH, uji Busa, Uji kelarutan serta uji antioksidan.

2. Agar dilakukan uji skrining sediaan sabun transparan dengan menggunakan metode angka lempeng total (ALT) pada penghambatan pertumbuhan bakteri uji dalam menentukan aktivitas antimikroba sabun transparan ekstrak jarak pagar . 


\section{DAFTAR PUSTAKA}

Badan Standarisasi Nasional., 1994.Standar Mutu Sabun Mandi. SNI 06-3532-1994. Dewan Standardisasi Nasional. Jakarta

Departemen Kesehatan RI. 1989. Materi Medika Indonesia Jld.IV. Departemen Kesehatan RI.

Djide,N., 2008. Analisis Mikrobiologi Farmasi. Universitas Hasanuddin, Makassar.

Februari, hal 96 - 104. Universitas Negeri Surabaya.

Garrity, George, M., Julia A. Bell., and Timotny G. Lhburr., 2004.Taxono \mic Outline of The Prokaryotes Bergey's Manual ${ }^{\circledR} \quad$ of Systematic bacteriology. Edisi kedua. Bergey's manual Trust : New York Heidelberg.

http:/ / freecochemistryone.blogspot.com/2012/11 /jurnal-pembuatan-sabuntransparan.html

Kasolo, JN., Bimeya, GS., Ojok, L., Ochieng, J., Okwal-okeng, JW.2010. Phytochemicals and Uses of Moringa oleifera Leaves in Ugandan Rural Communities. Journal of Medical Plant Research,4(9): 753-757.

Navie S., Steve C. 2010. Weed risk assessment, Horseradish tree (Moringa oleifera).Queensland Government

Pelczar, M, J., 1988. Dasar-Dasar Mikrobiologi.Penerjemah Ratna Sri Hadiotomo dkk. UI Press, Jakarta.

Qisti, Rachmiati. 2009. Sifat Kimia SabunTransparan dengan Penambahan Madupada Konsentrasi yang Berbeda. Bogor,Program Studi Teknologi Hasil TernakFakultas Peternakan Institut Pertanian, Bogor

Rahadiana, P., Andayani L.S. 2010. Pabrik Sabun Transparan Beraroma Terapi dari Minyak Jarak dengan Proses Saponifikasi Trigliserida Secara Kontinyu. ProgramStudi D3 Teknik Kimia FTI-ITS
Widiyanti, Yunita. 2009. Kajian Pengaruh Jenis Minyak terhadap Mutu Sabun Transparan.Fakultas Teknologi Pertanian,IPB. Bogor

USDA (United States Department of Agriculture). 2009. Natural Resources Conservation Service :PLANTS Profile Moringa oleifera Lam. Horseradishtree. http:/ / plants.usda.gov

Yaqin, Ainoel., et al. 2006. Sabun, detergen cair, bioetanol, Pengujian angka asetil, reichert meissl dan angka Polenske. Jakarta : UI 